Int. J. Dev. Biol. 61: 519-529 (2017)

doi: $10.1387 / \mathrm{ijdb} .160328$ op

\title{
Planaria: an animal model that integrates development, regeneration and pharmacology
}

\author{
ONÉ R. PAGÁN* \\ Department of Biology, West Chester University, West Chester, PA, USA
}

\begin{abstract}
Although planarians are established model organisms in developmental biology and regeneration studies, in the last forty years or so, they have caught the attention of pharmacologists, especially to study the pharmacology of drugs of abuse. This review covers the following topics: some fundamentals of the history of animal models and planarians in biomedical research; an abbreviated story of systematic pharmacology research using planarians as a model organism; an example of how planarians are contributing to the search for compounds against acute cocaine toxicity; an analysis of the number of papers on planarians and pharmacological topics from 19002016; some perspectives on pharmacology in developmental and regeneration studies, arguing in favor of the planarian model as a leading subject for this interdisciplinary area of research, and finally some concluding thoughts.
\end{abstract}

KEY WORDS: regeneration, pharmacology, development, planaria, Dugesia, Girardia, Schmidtea, Polycelis, Phagocata

\section{Introduction}

The study of model organisms for the purpose of uncovering fundamental biological principles is a leading source of multiple applications relevant to the medical sciences. When the original natural philosophers studied nature for pure knowledge's sake, they mainly followed Aristotle's maxim: "Philosophy starts in wonder and wonderment" (Aristotle, 384 BC). In time, not long after the medical sciences diverged from pure natural history, their true development was based on experimental science and the use of model organisms to better further our grasp of normal physiological mechanisms in humans, a tradition that continues to this day. As a consequence of this tradition, studies based on model organisms allow us to learn about the diseases that arise upon disruption of normal human physiology.

Most scholars agree that the beginnings of animal experimentation for the explicit purpose of advancing the biomedical sciences began in the 1800s with the French scientist Claude Bernard, the father of experimental physiology (Barker Jørgensen, 2001). Later on, in the early $20^{\text {th }}$ century the Danish experimental physiologist and Nobelist August Krogh independently articulated Bernard's insights when he stated:

"For a large number of [biological] problems there will be some animal of choice, or a few such animals, on which it can be most conveniently studied" (Krogh, 1929).
This statement lies at the heart of modern biomedical research, and was eventually formalized as "The Krogh Principle". This formalization was an idea of another Nobelist, Hans Krebs of the Tricarboxylic Acid Cycle fame-among several other important biochemical discoveries -(Krebs, 1975). Biologists have applied Krogh's Principle to virtually every aspect of the life sciences, but most importantly for the purposes of this review, to developmental and regeneration biology (Barker Jørgensen, 2001; Lindstedt, 2014). The contributions of virtually every model organism to experimental biology are exemplary illustrations of Krogh's Principle in action. Nevertheless, it is important not to lose sight of the fact that no particular organism is useful for every research problem. Also, not all aspects of the normal physiology of model organisms represent an ideal surrogate for human biology. These apparent deviations from Krogh's Principle were articulated by refining the principle through the following corollary:

"No single organism (or technique) exists that can provide easy access to the diversity of hidden mechanisms that underlie all interesting and important physiological and biochemical problems" (Wayne and Staves, 1996).

Although Krogh expressed his views on animal models in light of his own area of expertise (comparative physiology) and emphatically argued in favor of the practical applications of research, he, as Aristotle before him, possessed a keen aesthetic appreciation for the joy of pure biological knowledge. In Krogh's words:

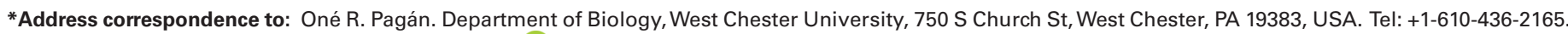
Fax: +1-610-436-2183. E-mail: opagan@wcupa.edu - (iD http://orcid.org/0000-0001-8232-7346
} 
"You will find in the lower animals mechanisms and adaptations of exquisite beauty and the most surprising character..." (Krogh, 1929).

I could not agree more with Krogh's appreciation of "lower animals", as I happen to work with one, a type of living being that exemplifies Krogh's practical yet lyrical description with distinction. This organism is the planarian.

\section{Planarians}

Although "planaria" and its derivations (planarian, planarians) are widely used to describe a specific type of common invertebrate, there is a minor controversy among specialists about using these terms in a formal scientific setting. Through informal conversations with colleagues, as well as by examining the scientific literature, it is evident that "planaria" is a rather nonspecific way of naming the organisms of interest. In essence, planarian merely means "flatworm", which by itself usually refers to a wide variety of organisms which may or may not be closely related phylogenetically (Egger et al., 2009). In fact, experts in the field have argued in favor of permanently discontinuing the use of "planaria" in the scientific literature (Egger et al., 2007). Only time will tell if this idea gains traction. Nonetheless, in this review, I will use "planaria" and related terms as traditionally used. In order to help in this discussion, I will define and describe what they are in the next paragraphs.

Planarians are essentially a series of several species of free-living flatworms that display bilateral symmetry. For the purposes of this review the planarians most commonly used for scientific research belong to the phylum Platyhelminthes, whose most famous and highly successful members include a variety of obligate parasites that are beyond of the scope of this review (Collins, 2017). The best known examples of the free-living Platyhelminthes belong to the order Tricladida, a classification criterion based on specific aspects of their digestive system morphology (Rohde, 2000). Triclads are traditionally further classified based on an ecological context, namely whether they live in freshwater, marine, or terrestrial environments. This ecological classification scheme of triclads is not universally accepted and is under revision using molecular biology approaches (Alvarez-Presas etal., 2008; Riutort et al., 2012). Most of the planarian species used as research animals are freshwater species. The most common genera used in research are Girardia, Dugesia; (Fig. 1), Schmidtea, Phagocata, and Polycelis (Elliott

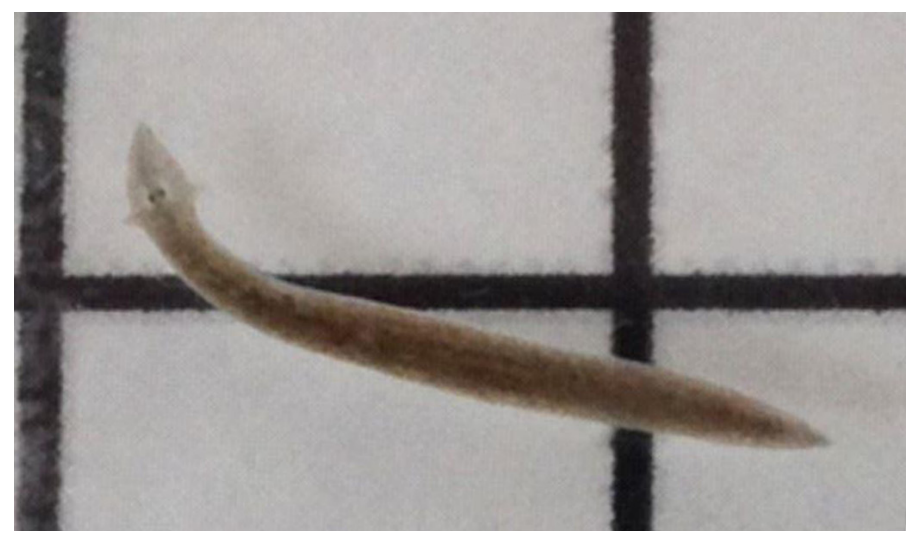

Fig. 1. Planarian specimen (Girardia sp.) over a 1-cm gridline. Picture credit: Pagán Laboratory.
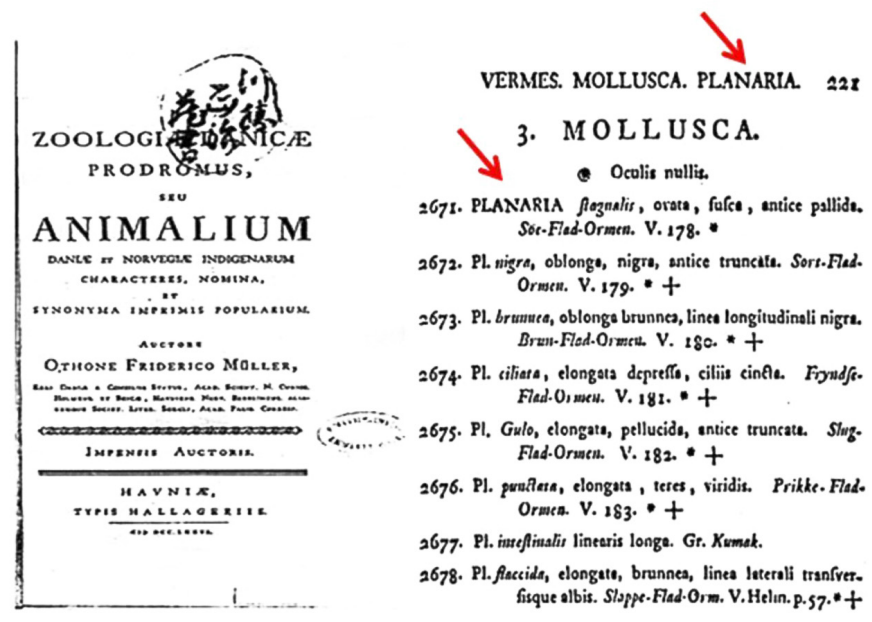

Fig. 2. Cover of Müller's Prodromus (left) and the page where "planaria" appeared for the first time (right). Please note that at the time, planarians were classified as mollusks. Photograph courtesy of Dr. Masaharu Kawakatsu, used with permission.

and Sánchez Alvarado, 2013, Newmark and Sánchez Alvarado, 2002; Saló and Baguñà, 2002; Tessmar-Raible and Arendt, 2003). Girardia and Dugesia are the best-known genera with about 75 identified species so far (Riutort et al., 2012).

Historically, it seems that the earliest printed reference of the term "planaria" came from the Danish naturalist Othone Friderico Müller in a 1776 book titled "Zoologiae Danicae Prodromus" (Fig. 2). It is to be noted that many of the flatworm species that Müller called "planarians" are currently placed into other taxa of the class turbellariaor the phylum rhynchocoela (Alvarez-Presas et al., 2008; Riutort et al., 2012).

Although it is undisputable that Müller deserves priority recognition for the use of the term "planaria", two years before Müller's book, in 1774, the German naturalist Peter Simon Pallas published his book Spicilegia Zoologica, where he showed drawings of several worms which for all intent and purposes look like planarians. However, he listed these worms as Fasciola, a name that now is reserved for a genus of parasitic flatworms (Fig. 3). His drawings were so precise and detailed that modern specialists are able to identify the depicted planarian species with a high level of certainty.

In the best tradition of the scientific "Age of Wonder" of the 1700s1800 s, planarians were enthusiastically studied by the naturalists of the time, including Charles Darwin (Elliott and Sánchez Alvarado, 2013; Rieger, 1998; http://darwin-online.org.uk/). Even the father of modern genetics, Thomas Hunt Morgan, studied planarians. Between 1898 and 1905, Morgan published a series of papers and books on the general topic of regeneration, with planarians as one of the main research subjects (Sturtevant, 1959). According to Morgan himself, planarians came to his attention by reading a paper by Dr. Harriet Randolph, of Bryn Mawr College (Randolph, 1897). Randolph and Morgan collaborated in subsequent works. In great part as a consequence of this collaboration, Morgan even seriously considered planarians as his choice of model organism to study the cellular basis of genetics before favoring the fruit fly, Drosophila melanogaster (Adell et al., 2010; Gentile et al., 2011; Newmark and Sánchez Alvarado, 1999; Pagán, 2014, chapter 7). There is little doubt that if planarians had been Morgan's choice, 


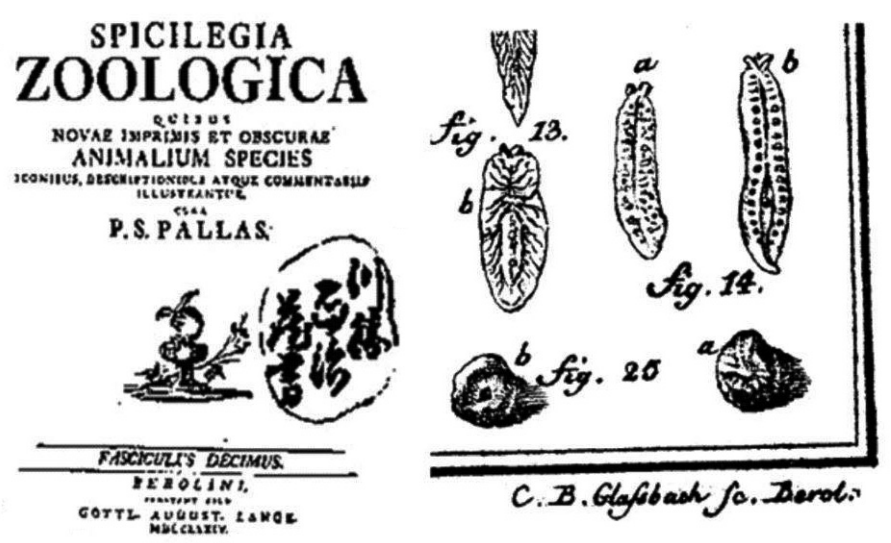

Fig. 3. Cover of Pallas' Spicilea Zoologica (left) and the page showing some worms which are very much like planarians (right). Photograph courtesy of Dr. Masaharu Kawakatsu, used with permission.

the history of $20^{\text {th }}$ century genetics could have featured a different protagonist!

The history of planarians in biology is quite curious to say the least. There were two specific time periods in which despite an initial interest in the worms, researchers stopped using them as animal models in favor of other organisms, for a variety of reasons. Some authors have speculated on the specific reasons for this apparent decline of scientific interest. The first of such time periods was around Morgan's time, in a series of well-documented episodes described and analyzed in detail in a work appropriately titled: "Whatever happened to planaria?" (Mitman and FaustoSterling, 1992).

The reason for the second time period of low popularity of planarians (roughly the 1950s-1960s) is not entirely clear and is therefore more debated, but this seemed to be related to the (at the time controversial) research by James McConnell on memory transfer experiments using planarians (Rilling, 1996). McConnell also worked, albeit somewhat less controversially, on memory retention in trained planarians upon decapitation and brain regeneration (reviewed in Corning and Ratner, 1967; Pagán, 2014; Rilling, 1966). Incidentally, McConnell's memory retention work has recently been replicated using computerized procedures and properly designed controls, which renders the concept valid beyond any scientific doubt (Blackiston et al., 2015; Neuhof et al., 2016; Shomrat and Levin, 2013). Memory research using planarians is undoubtedly experiencing an exciting resurgence, but this topic is beyond the scope of this review.

Planarians are uniquely situated to contribute to several scientific disciplines, including neurobiology. In evolutionary terms, they are some of the simplest examples of organisms displaying bilateral symmetry and cephalization, including a primitive "brain", with many features similar to vertebrate nervous systems (Sarnat and Netsky, 1985, 2002). Depending on the actual definition of what a "brain" is (for example see Netsky, 1986) it is generally believed that planarians represent the first type of organism possessing an actual brain (Agata et al., 1998; Cebrià, 2007; Pagán, 2014; Sarnat and Netsky, 1985, 2002; Okamoto et al., 2005; Umesono et al., 2011). In addition to the general features of the planarian nervous system that are similar to the nervous systems of more "advanced" organisms, planarian neurons display closer similarities to vertebrate neurons than to invertebrate neurons like insects, for example, in terms of cell morphology and physiology (Sarnat and Netsky, 1985, 2002). Structurally, the planarian central nervous system consists of an anterior brain (sometimes referred to as cephalic ganglia) and two longitudinal nerve cords, connected to each other with nerve fibers arranged in a ladder-like structure (Cebrià, 2007; Lentz, 1968; Okamoto et al., 2005; Fig. 4). Interestingly, most major neurotransmitter systems found in vertebrates are also found in the planarian nervous system, which further argues in favor of using this animal model in neurobiological investigations (Buttarelli et al., 2008; Carolei et al., 1975; Ribeiro et al., 2005).

Additionally, planarians display a surprising variety of behavioral responses induced by a wide range of compounds (for descriptions of some of such behaviors please see Akiyama et al., 2015; Inoue et al., 2015; Cochet-Escartin et al., 2015; Paskin et al., 2014; Raffa et al., 2001; Raffa and Desai, 2005; Rawls et al., 2011; Talbot and Schötz, 2011; Tallarida et al., 2014). These characteristics makes planarians exceptional animal models in neurobiology, but their usefulness does not stop there. Their varied and relatively complex behavioral responses and the parallels between the anatomy and physiology of the vertebrate and the planarian nervous systems resulted in the development of planarians as a popular animal model in pharmacology and its sister science, toxicology (Alonso and Camargo, 2015; Best and Morita 1991; Li, 2016; Pagán et al., 2009; Schaeffer, 1993; Stevens et al., 2015). In this review, I emphasize the usefulness of planarians in pharmacological studies, particularly in terms of neurobiology \& behavior. For two excellent reviews on planarian toxicology please see Hagstrom et al.,2015, 2016).

\section{The beginnings of systematic planarian pharmacology research}

When considering the fact that planarians share many biological features with "higher" organisms, together with their interesting drug-induced behaviors, as well as their ease of use, it is no surprise that planarians found their way into systematic pharmacological research. In retrospect, it is rather surprising that it took so long. It is important to point out that most of the pre-1970 planarian research was not conducted with the explicit purpose of studying pharmacology, even though many compounds were tested in

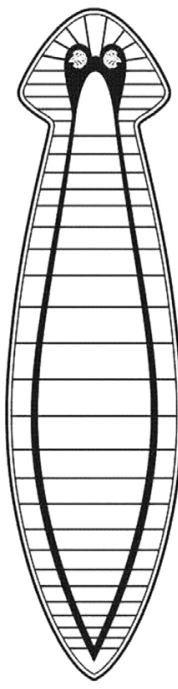
this invertebrate. Rather, the main objective was to use particular compounds in order to exploit their specific pharmacological properties, by slowing down or even paralyzing the worms to facilitate the study of their anatomical or physiological characteristics. In fact, up to the 1970s, there were quite a few publications describing the effects of a variety of compounds and drugs on planarians. More recently, the main emphasis on the use of planarians in the pharmacological sciences are the specific fields of behavioral- and neuro-pharmacology (Buttarelli et al., 2008; Raffa and Rawls, 2008). In the late 1960s-early 1970s scientists began to realize that planarians showed relatively complex behaviors when exposed to

Fig. 4. A general representation of the planarian nervous system. Courtesy of Mr. Alexis G. Pagán. 
substances that induced psychoactive effects in "higher" organisms, including vertebrates. Most interestingly, these worms displayed various types of behavioral responses when exposed to drugs like nicotine and cocaine. These planarian behaviors were evocative of behaviors displayed by humans upon abused drug use, particularly withdrawal-like behaviors related to physical dependence. These facts caught the attention of clinical scientists, who reasoned that planarians could be useful as models for the pharmacology of drug abuse and other neurological diseases. In this light, the very first report on the effects of a drug of abuse in planarians (morphine; Needleman, 1967), was reported by a physician, Dr. Herbert Needleman of Temple University, the pediatrician/psychiatrist who is best known for his groundbreaking work on the neurotoxicity of lead exposure and its effects on public health.

An ocean away in Rome, Italy, Drs. Antonio Carolei, Vito Margotta, and Guido Palladini, neurologists at the University La Sapienza, Rome, pioneered the systematic use of planarians in pharmacology with the publication of their 1975 paper: "Proposal of a New Model with Dopaminergic-Cholinergic Interactions for Neuropharmacological Investigations" (Carolei et al., 1975), coincidentally, the same year when Krogh's Principle was formalized (Krebs, 1975).

Once again, the remarkable regenerative properties of planarians were behind the interest of biomedical scientists, leading to the use of these organisms as animal models. According to Dr. Carolei (personal communication), in the 1970s he had a scientific conversation with Dr. Palladini, that touched upon the topic of immortality. Dr. Palladini observed that planarians were part of a select group of animals that showed the potential for immortality due to their unusual regeneration capabilities. This comment sparked Dr. Carolei's interest in planarian biology. Their formal scientific rationale to study planarians was the analogous neural networks of the motor system of planarians with the extrapyramidal system of vertebrates, particularly their cholinergic/dopaminergic interactions. The extrapyramidal system is a series of neuronal structures that control multiple aspects of motor responses in vertebrates. The dysfunction of this system leads to a variety of movement disorders in humans, with Parkinson's Disease as probably the best-know example (reviewed in Dorman, 2015). In a short time, Drs. Carolei, Margotta, and Palladini, along with several other colleagues, began to explore planarians as animal models for neurological diseases with a neuropharmacological emphasis, and published close to forty papers or book chapters between 1975 and 2008 on the pharmacology and neurobiology of the planarian Dugesia gonocephala, also known as Dugesia japonica (reviewed in Buttarelli et al., 2008 and in Carolei et al., 2008a,b). Their planarianrelated publications dealt with a variety of pharmacological topics, including the role of various neurotransmitter systems as well as the effects of abused drugs like opiates, cannabinoids, and cocaine (reviewed in Buttarelli et al., 2008 and in Carolei et al., 2008a,b). In fact, they published the very first two papers that explicitly explored the effect of cocaine in this experimental organism (Palladini et al., 1996; Margotta et al., 1997). Planarians seemed to have a special affinity for experimental neurologists; Drs. Harvey B. Sarnat and Martin G. Netsky, then at UCLA, argued for the use of planarians in the neurosciences (Sarnat and Netsky, 1985, 2002).

Thanks to the works of the se clinical scientists, planarians caught the attention of a group at Temple University, led by Dr. Robert Raffa. Although a "traditional" pharmacologist, in his undergraduate university years he read about planarians in the context of
James McConnell's memory retention work. Later on, Dr. Raffa began his research projects on planarians at the suggestion of a former colleague, and eventually joined efforts with another Temple University pharmacologist, Dr. Scott Rawls. In 2000, the Temple group published their first planarian pharmacology paper, which was on the antipsychotic sulpiride and its antagonistic properties against the neurotransmitter dopamine. As Drs. Carolei and Palladini before them, Raffa's research was inspired on the similarities between the planarian and mammalian dopaminergic systems (Raffa et al., 2000). In 2001, the Raffa group published their first cocaine/planaria paper (Raffa and Valdez, 2001), which was about a series of behaviors reminiscent of "withdrawal symptoms" upon exposure to cocaine to planarians. Just as the Rome team did, the Temple University team began to explore (and continue exploring at the time of this writing) the pharmacology of planarians. The planarian pharmacology emphasis of the Temple team was (and still is) abused drugs and their generation of specific planarian behaviors that are similar to drug-related addiction behaviors in vertebrates. Their chosen planarian species is Girardia dorotocephala. From the year 2000 to date, this group has published close to 50 peer-reviewed papers or book chapters on planarian behavioral pharmacology. Some of the specific drug-related topics that the Temple group study in their planaria-related research include cross-sensitization (Rawls et al., 2010), anxiogenic-like responses (Nayak etal., 2016), dose-related physical dependence (Raffa et al., 2007), the dependence of drug exposure duration related to the withdrawal response (Sacavage et al., 2008), and abstinence-induced withdrawal among other related effects (Raffa et al., 2008). Some drugs of abuse that were tested in their work included cocaine, nicotine, amphetamines, opioids, cannabinoids, and cathinones among others. Their work has been partially reviewed in Raffa and Rawls (2008).

Again, just like the Rome group did, the Temple group gathered significant evidence indicating that planarians represents an interesting animal model, but more importantly, they further established planarians as a model that displays close parallels with vertebrate pharmacology. Both groups undoubtedly validated the usefulness of these invertebrates in pharmacological research in general and on the pharmacology of abused drugs in particular.

\section{Planarians and the search for cocaine antagonists}

One of the immediate research directions related to the pharmacology of drug abuse is the identification of compounds capable of alleviating the behavioral or toxic properties of drugs. A premier example of this approach was the development of naloxone as an antidote against opioid overdose (Strang et al., 2016). An abused drug that has resisted this approach is cocaine, which is an excellent local anesthetic that is nonetheless a highly addictive substance that has proved to be the direct cause of many overdose-related fatalities (Loper, 1989; for a brief overview of the history and pharmacology of cocaine please see Pagán, 2014, chapter 5). So far, the identification of a substance useful to clinically treat cocaine intoxication has proven elusive (reviewed in Connors and Hoffman, 2013). There are several interesting links between planarians and cocaine. Based on the most current available information online, the two earliest publications describing planarian-like organisms exposed to cocaine were an anonymous note in the journal The American Naturalist (1891) and the second one was a report by 
Dr. Harold Heath, on the identification of a planarian species from Hawaii, published in the Proceedings of the Academy of Natural Sciences of Philadelphia (Heath, 1907). In both these works, the main objective of using cocaine was to narcotize the worms so they could be better examined.

It is important to point out that in the 1891 paper, the observed organism, although called a planarian, was actually another type of flatworm, an acoel, which is no longer recognized as a planarian in phylogenetic terms (Ruiz-Trillo et al., 1999). Also, Dr. Heath's paper dealt with a marine flatworm, albeit a polyclad, which differs from the "traditional" triclad planarians that we are discussing here (Alvarez-Presas et al., 2008). Therefore, in strict terms, to the best of my knowledge, the very first publications on planarians and cocaine came from the Rome group, as discussed in the previous section (Palladini et al., 1996; Margotta et al., 1997), followed by the aforementioned publications of the Temple group. This means that in strict terms, planarian/cocaine research is a mere 20 years old at the time of this writing. I am honored by the fact that my own laboratory has also provided information on the cocaine/planarian connection. I feel fortunate of having had the opportunity to contribute to this scientific story and to continue doing so. What follows is a brief account of the efforts of my research group at West Chester University on the identification of behavioral cocaine antagonists using the planarian model.

Parthenolide (Fig. 5) and related molecules are naturallyoccurring chemicals belonging to a class of compounds called sesquiterpene lactones, which display a wide range of biological effects; these compounds are commonly found in several species of plants of the Asteracea family, parthenolide in particular is mainly isolated from the feverfew plant (reviewed in Ivanescu et al., 2015 and in Pagán, 2005, chapter 5).

Preliminary data from my PhD dissertation (Pagán, 2005, chapter 5) indicated that parthenolide showed antagonistic activity against cocaine on both the nicotinic acetylcholine receptor and the dopamine transporter using cell-based assays (reviewed in Pagán, 2014, chapter 10). Based on these data, once I became an independent investigator, I decided to study whether parthenolide or related compounds display anti-cocaine activity in vivo, as opposed to the ex vivo (cell-based assays) approach previously mentioned. Due to the multiple advantages that the planarian model offers, and inspired by planarians papers dealing with their neurobiology and pharmacology (Raffa and Valdez, 2001; Raffa and Desai, 2005; Sarnat and Netsky, 1985, 2002), I chose these worms as my experimental organism.

Our research demonstrated that parthenolide and related compounds indeed act as cocaine behavioral antagonists on the planar-

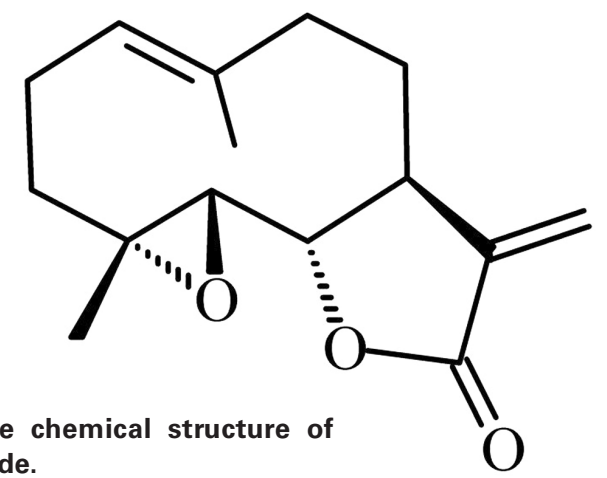

ian model. Parthenolide antagonizes cocaine under conditions of both acute administration (Pagán et al., 2008) as well as chronic administration, effectively preventing the expression of withdrawallike behaviors (Rowlands and Pagán, 2008). We also explored the structural features of parthenolide-like molecules that endowed them with the ability to act as cocaine antagonists in planarians (Baker et al., 2011), and provided evidence indicating that parthenolide is a specific cocaine antagonist in this model (Pagán et al., 2012). Also, using behavioral techniques developed in our laboratory, we obtained information about the relative localization of the putative binding sites of cocaine and nicotine in the planarian nervous system (Pagán et al., 2013). Moreover, our collaborators at the University of Puerto Rico, led by Dr. Carlos Jiménez-Rivera, found that parthenolide blocks the effect of cocaine on the spontaneous firing activity of dopaminergic nerve cells in the ventral tegmental area of rats (Schwartz et al., 2010), therefore validating the Rome group's original insight; planarian pharmacology does indeed seem to translate to vertebrate pharmacology, particularly that of mammals (Buttarelli et al., 2008). To the best of my knowledge, there are no other research groups using planarians to search for antagonists of drugs of abuse, and much more work needs to be done in this exciting area of research. This story is far from over. In the next section, we'll explore some trends about the scientific publications on planarians and the pharmacological sciences.

\section{A survey of published papers dealing with planarians and pharmacology: 1900-2016}

I began this review with the Krogh's Principle as applied to model organisms. Interestingly, the very same paper where he published his insights on animal models (Krogh, 1929), included a thorough analysis of the published papers on experimental physiology over time, an approach similar to the one that I applied in this section, with one major difference: Krogh did not have the advantage of electronic databases to help him. I simply need to express my admiration for his hard labor. On this note, for this section I used the NIH's PubMed database (http://www.ncbi.nlm.nih.gov/pubmed). The searches included up to December 2016. Obviously, the results reported here will be slightly different than the searches performed at the time of publication of this review, as more papers are being added to the PubMed database. However, this data will give us a good idea on the publication trends related to planarians and pharmacology. Also, please note that by necessity I chose the search keywords arbitrarily. For example, to search articles about planarians, I used the following array:

SEARCH 1 = (girardia OR dugesia OR schmidtea OR polycelis OR phagocata OR planaria OR planarian OR planarians)

Which represent the five planarian genera that are most commonly used as research subjects as well as the variations on the "planarian" term. I did not include terms like "flatworm" in these search keywords because the results would then have included papers about non-planarian organisms, like parasitic worms and acoels, for example, which although quite interesting in their own right, are beyond the scope of this review.

To search for the papers about pharmacology and planarians I used the following array:

SEARCH 2 = (girardia OR dugesia OR schmidtea OR polycelis OR planaria OR phagocata OR planarian OR planarians) AND (pharmacology OR drug OR drugs OR pharmacological) 
The overall results for both SEARCH 1 and SEARCH 2 are shown in Fig. 6. The data shows that of the planarian-related papers published between 1900 and 2016, approximately $24 \%$ were of a pharmacological nature.

Next, I refined the results by using the PubMed feature that allows for the custom selection of publication dates, as shown in Fig. 7.

The data in Fig. 7 indicates that there is a clear trend showing an increase on the number of planarian papers per year. The same applies to planarian pharmacology papers, albeit to a lesser extent, as expected due to the search constraints. Interestingly, the data show a decrease on the number of planarian papers per year between 1971 and 1990, which roughly correlates with the decrease in popularity of the planarian model as a consequence of the aforementioned controversial research of James McConnell. Curiously, when the data are plotted as the fraction of planarian papers dealing with pharmacology (Fig. 7, inset), it shows that about $40 \%$ of the planarian papers published between 1971 and 1990 were related to pharmacology. It seems that even though planarians lost some popularity among the general scientific population, it gained a relatively higher interest from pharmacologically-minded scientists, arguably inspired by Dr. Carolei's 1975 paper (Carolei et al., 1975). For the last 25 five years or so, the percent of planarian papers related to pharmacology has stabilized to about $24 \%$ of the total planarian-related papers (Fig. 7, inset), in close agreement with the data shown in Fig. 6.

Please note that this database strategy used in this work is limited by the fact that by necessity one needs to work with the keywords explicitly stated anywhere within the text. This means that there will be papers that albeit of a pharmacological nature, may escape this search strategy because pharmacology-related terms may not be explicitly stated in the text. Case in point: the two earliest papers that came up in the planarian search (Moore, 1918; Stringer, 1917) dealt with the behavioral effects of strychnine on planarians and starfish, and the effect of lithium chloride and magnesium chloride on planarian locomotion respectively. Both papers are undoubtedly pharmacological in nature, yet they were not "caught" by the search. The main implication of this limitation is that we are seeing an underestimation of the pharmacological-themed planarian papers. To minimize this limitation, when searching for

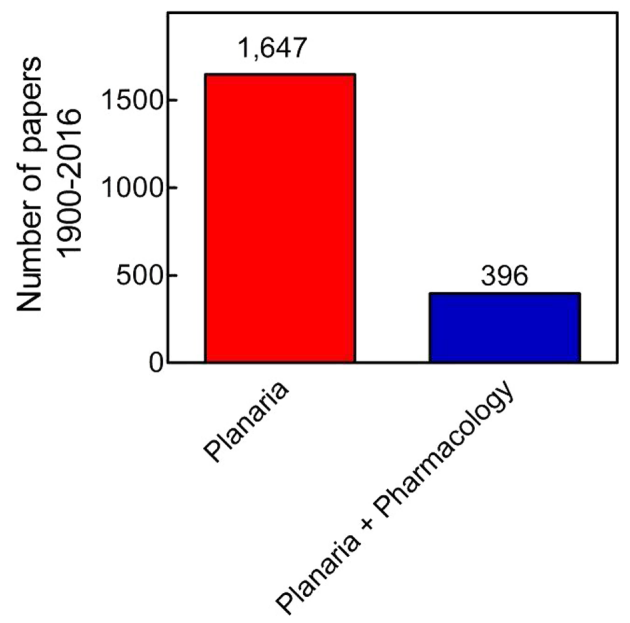

Fig. 6. Published papers on planarians (SEARCH 1, see text), and on planarians and pharmacology (SEARCH 2, see text). The numbers on top of the bars represent the number of papers.

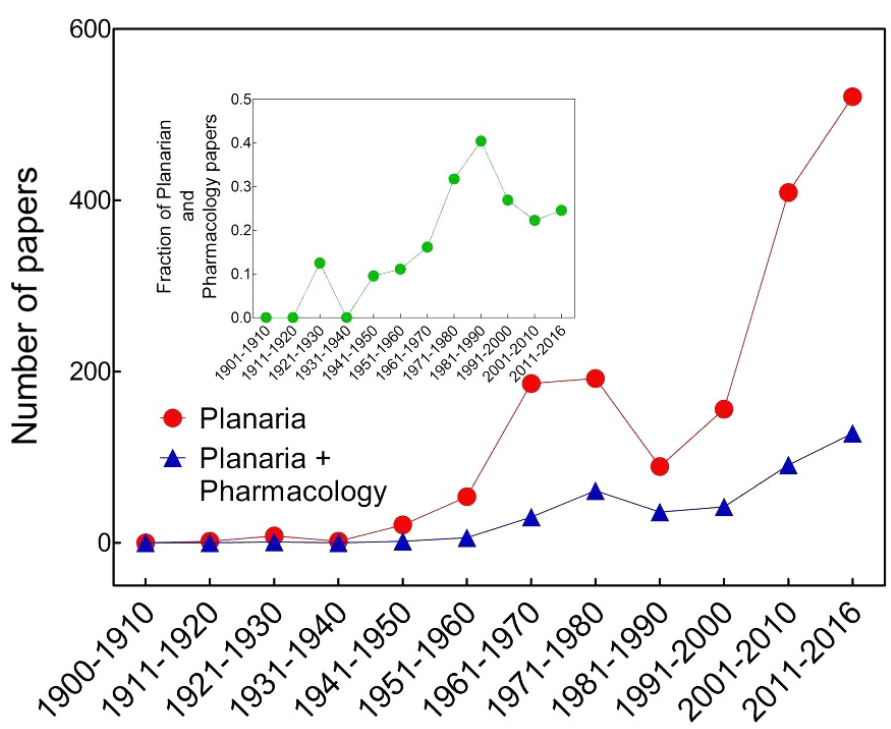

Fig. 7. Planarian (SEARCH 1) and planarian/pharmacology papers (SEARCH 2) 1900-2016. Inset: Fraction of planarian papers that dealt with pharmacological aspects (see text).

planarian papers on drugs of abuse, I used SEARCH 1 combined with the appropriate keywords (i.e., cocaine, cannabinoid, etc.) as shown in Fig. 8.

Fig. 8 shows an increasing trend in the publication of planarianrelated papers with a pharmacological theme, specifically about drugs of abuse. The inset shows the number of planarian papers that include keywords related to specific abused drugs 1900-2016, as indicated. It is fully expected that this trend will continue.

\section{The future: developmental and regeneration pharmacology: Planarians lead the way.}

Regular readers of this journal are quite familiar with the formal distinctions between the processes of development and regeneration. Therefore, I will not revisit their respective definitions here except to say that these are two closely related areas, with important similarities and differences in terms of their specific mechanisms and physiological aspects. Nonetheless, in many instances they are treated as one and the same phenomenon, even in scientific publications, which oftentimes leads to controversy, a controversy that is beyond the scope of our discussion. For a review of the similarities and differences between the phenomena of development and regeneration please refer to Vervoort (2011).

Efforts regarding the advance of developmental pharmacology are mainly focused on the neonatal and pediatrics application of such principles (Kearns et al., 2003; Samardzic et al., 2015). The overwhelming majority of the literature in this area deals primarily with aspects of dosage, as well as the ADME pharmacological principle (Administration, Distribution, Metabolism, and Elimination) and their effect on the normal development of young patients. These young patients were widely referred to as "therapeutic orphans" because of the relative lack of data regarding the effects of age on pharmacological treatments (Berde and Cairns, 2000). I was unable to obtain any publications on the correction of fully understood developmental defects through pharmacological approaches. Probably the only example of this practice in preventive medicine 


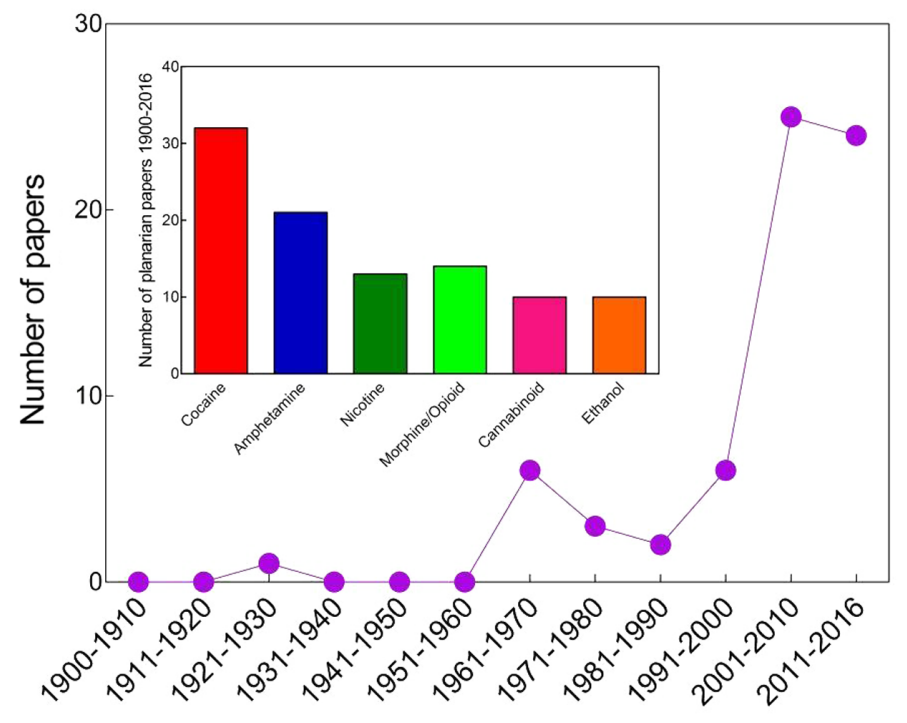

Fig. 8. Planarian (SEARCH 1) combined with various search terms associated with drugs of abuse as indicated in the inset. (SEARCH 2) 1900-2016. Inset: The same data separated into the individual drugs of abuse, as indicated.

is the supplementation of folic acid to pregnant women, shown to decrease the risk of neural tube defects, a congenital defect that prevents the proper closure of the neural tube. However, even in this case, the genetic and biochemical mechanisms of such protective effect are largely unknown (Imbard et al., 2013).

As in the case of developmental pharmacology, most of the scientific literature on regeneration pharmacology is oriented towards applications to the clinical sciences, specifically with the repair of various organ systems. In fact, a formal definition of the field of regenerative medicine in general is the "... repair and/or replacement of damaged cells, tissues, and organs for functional restoration" (Christ et al., 2013). Regeneration pharmacology aims to the integration of several "traditional" aspects of regenerative medicine, namely molecular biology, biomaterials and tissue engineering, nanotechnology, and physiology among others, with a pharmacological approach (Andersson and Christ, 2007; Christ et al., 2013).

In this final section of this review, I argue in favor of planaria as the proverbial "flagship" animal model in developmental pharmacology and regeneration pharmacology. This class of organisms possesses a unique set of characteristics that makes it particularly endowed to serve as a link to connect the research efforts of scientists of different disciplines.

Planarians have long been proposed as useful animal models for regenerative medicine (Gentile et al., 2011; Karami et al., 2015; Matthews and Levin, 2016; Umesono et al., 2011). Also, traditionally, planarian worms have been used as an animal model in developmental biology, mainly because many planarian species possess the extraordinary ability of completely regenerating lost body parts (Reddien and Sánchez Alvarado, 2004; Sánchez Alvarado, 2006; Newmark et al., 2003; Sánchez Alvarado, 2004a,b). In strict terms, most organisms are capable of some degree of regeneration, and in general, the closer they are to the vertebrate line, the lesser the regenerative abilities they may display. There are other organisms which are as remarkable, if not more, as planarians are in terms of regenerative properties. Well-known examples are certain sponge species and the small freshwater cnidarian hydra. These two types of organisms tolerate complete cell dissociation and in the absence of any chemical insults, are able of reforming their entire body structure (Alexander et al., 2015; Holstein et al., 2003). This is an extreme capability not shared by planarians. It is without dispute that sponges and cnidarians are invaluable regeneration models. What sets planarians apart in terms of regeneration and development is that they are relatively complex organisms in terms of organ structure (Roberts-Galbraith et al., 2015). Moreover, the regenerative prowess of some planarian species include the complete regeneration of the brain and nervous system (Agata and Umesono, 2008; Cebrià, 2007; Cebrià and Newmark, 2002; Cebrià et al., 2002; Fraguas et al., 2012; Umesono and Agata, 2009; Umesono et al., 2011). These facts, alongside the aforementioned relatively complex behaviors that these organisms express naturally and in response to exposure of a variety of drugs, make planarians unique organisms to integrate the fields of regeneration, developmental biology, and pharmacology.

Another advantage of the use of the planarian model in this context is that they are very well characterized in genomic terms. Since 2007, the Schmidtea mediterranea Genome Database (SmedDB; http://smedgd.stowers.org), now in its second generation (Robb et al., 2015) has provided a much needed resource where genomic and transcriptomic studies from this organism are compiled (For examples please see Abril et al., 2010, Nishimura et al., 2012, and Resch et al., 2012). Transcriptomic analyses have also been performed in Dugesia japonica (Chan et al., 2016; Nishimura et al., 2012, 2015; Pang et al., 2016; Qin et al., 2016).

As useful as molecular approaches are, allow me to offer a note of caution on the use of inbred and clonal strains from a pharmacological perspective. Natural populations of any organism will generally display some degree of genetic variability. This is an integral aspect of the evolutionary process. This means that in such natural populations we would expect to see a correspondent degree of variability in the pharmacological responses induced by any tested drug or toxin. The human pharmacogenetic variability observed by the expression of multiple phenotypes in response to a single drug also applies to our fellow organisms on this planet. The study of the pharmacologically diverse effects on non-homogeneous populations will paint a more realistic picture of the incidence of any pharmacologically-related phenotypes than studies on clonal lines. Natural populations are exposed to various types of environmental stimuli that contribute to selective pressure, an established occurrence that is widely considered a driving force on evolution, whether it comes from biotic or abiotic factors. One of the consequences of such pressure is genetic heterogeneity in a population. In these lines, the planarians currently used to model the genetic data ( $S$. mediterranea and Dugesia japonica) are usually more genetically uniform than natural populations. It is important to reiterate that there is no doubt that studies on clonal lines provide essential information about fundamental biological processes. Nonetheless, I submit that any pharmacological conclusion based exclusively on such planarian clonal lines must be examined in light of data obtained from more natural populations in order to refine and complement the information obtained through populations of genetically similar organisms. Several species of planarians of the Girardia, Dugesia, and Phagocata genera are currently commercially available through several suppliers and are 
therefore available for such pharmacological studies.

Another important bioinformatics approach designed to store and disseminate planarian regeneration-related research is the development of the Planform database (PlanformDB; http://lobolab.umbc. edu/planform/; Lobo et al., 2013). This database collects more than a thousand separate published experiments and just as SmedGD, PlanformDB is under constant expansion. In contrast to SmedGD, PlanformDB includes information from a wider range of planarian species. There is little doubt that SmedGD and PlanformDB complement each other and their interaction will surely facilitate the exchange of information between scientists across different disciplines, significantly advancing the progress of planarian research.

A recent series of quite interesting experiments perfectly showcase the integration of the disciplines of development, regeneration, and pharmacology. The research that I will briefly describe comes from the laboratory of Dr. Michael Levin of Tufts University. The basis of their work is the recognition that bioelectrical properties play a central role in regeneration phenomena (Durant et al., 2016; Levin 2012, 2014). Specifically, they have explored the pharmacological manipulation of gap junctions, which are channels between cells formed by specific proteins (connexins) that modulate the connections between cells. Connexins selectively allow the exchange of their internal components, which frequently include ions. Thus, these proteins modulate the bioelectrical properties between cells. These proteins are being recognized as modulators of the planarian stem cell response as related to tissue maintenance, repair, and remodeling (Peiris and Oviedo, 2013).

By pharmacologically treating planarians with n-octanol, a connexin blocker, they were able to modulate the physiology of planarian stem cells from Dugesia japonica to induce the formation of multiple heads and their associated neural structures (Oviedo et al., 2010). In a related note, ectopic brain tissue formation in planarians was also observed a few years ago by modulating the function of fibroblast growth factor receptors (Cebrià et al., 2002). The recent work by the Levin laboratory describes a series of experiments (Emmons-Bell et al., 2015) in which they treated decapitated planarians of a commercially available planarian species (Girardia dorotocephala) with $123 \mu \mathrm{M} \mathrm{n}$-octanol for three days. After this period, the n-octanol was washed away and the worms were allowed to regenerate for seven additional days. Many worms regenerated normally (about $35 \%$ of the total), but a significant fraction of them differed drastically on their head morphology; these worms' head shapes were closely similar to the head shapes of different planarian species, which they referred to as "pseudo-X", X being Girardia dorotocephala, Dugesia japonica, Polycelis felina, and Schimidtea mediterranea(Fig. 9). In addition to the appearance of various head shapes in the regenerating planarians, three additional aspects of this series of experiments are quite significant: (1) The proportion of the head shapes developed of the total planarians tested (i.e., the relative percentages of pseudo-Girardia, pseudo-Dugesia, pseudo-Polycelis, and pseudo-Schmidtea), (2) Their associated brain structures and distribution of neoblasts (planarian stem cells), and (3) The eventual return to the original Girardia-like head shape, as if the original genome of the planarian was "reasserting" itself. In brief, the number of planarians regenerating specific head shapes roughly correlated with the phylogenetic distance from the parent species ( $G$. dorotocephala). Most of the worms regenerated the parent form ( 35\%), followed by pseudo-D. japonica $(\sim 30 \%)$, pseudo-S. mediterranea ( 15\%), and pseudo-P. felina ( 5\%; Fig.

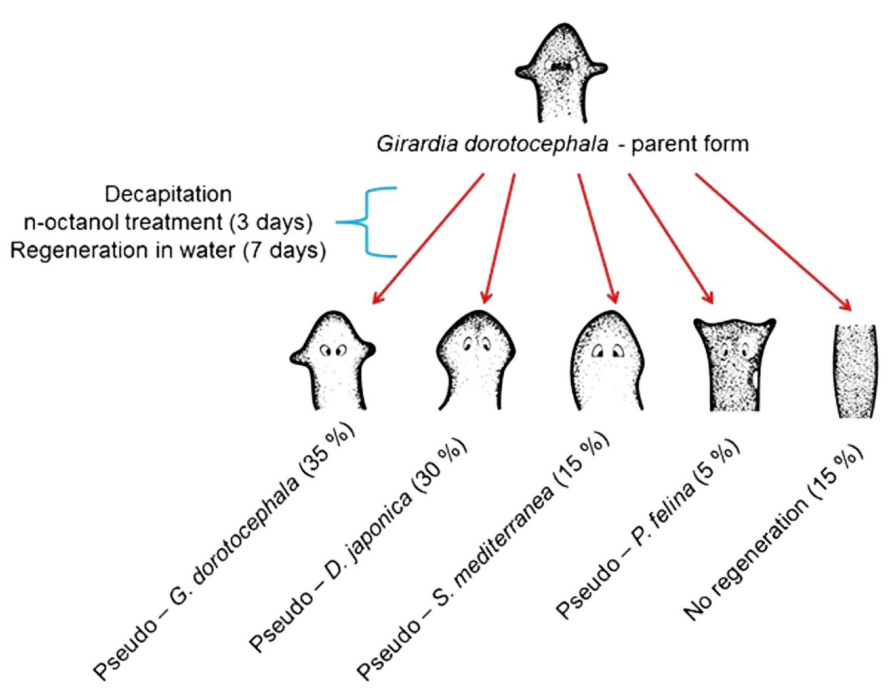

Fig. 9. Excerpt of the main results of Emmons-Bell et al., (2015) on the transient pharmacological modification of the apparent phenotype of regenerating Girardia dorotocephala (see text). Illustration courtesy of Mr. Alexis G. Pagán.

9). Fifteen percent of the worms failed to regenerate. Interestingly, the morphological differences were not limited to their head shape; their brain connectivity and overall morphology were changed as well, resembling that of the "pseudo" species. Finally, the change in head morphology was transient. When the worms were allowed to regenerate beyond day 10 , they reverted to a shape similar to the parental form, again, roughly in phylogenetic distance order, as if their "native" genome was reactivated. This differed from previous experiments where the formation of additional heads in $D$. japonica was a permanent phenomenon (Oviedo et al., 2010). The Levin group further proposed the beginnings of a model that describes how bioelectrical properties can be manipulated to generate distinct morphologies.

From the perspective of the main topic of this review, the results described in Emmons-Bell et al.,2015) seems to represent the first demonstration where pharmacology, regeneration, and development were explicitly related in an experimental framework. In essence, the pharmacologica/manipulation of connexins disrupted the normal regeneration of $G$. dorotocephalato $G$. dorotocephala, inducing the development of the pseudo- $D$. japonica, pseudo-S. mediterranea, and pseudo- $P$. felina heads as well as their corresponding brain morphologies, which subsequently "re-developed" into their original phenotype. If and when developmental biology, regeneration biology, and pharmacology become truly integrated into a bona fide area of research, Emmons-Bell et al.,2015) should be recognized as a landmark study of this emerging interdisciplinary field.

\section{Conclusions and Perspectives}

The fields of planarian pharmacology and neuroscience are undergoing an interesting period of expansion. This includes the exciting interdisciplinary areas of developmental and regeneration pharmacology. I strongly believe that the interdisciplinary nature of this novel approach using planarians must begin with a perspective shift on behalf of the relevant scientists. In other words, a pharmacologist should be as conversant and comfortable talking 
about imaginal discs and stem cells as when talking about receptor theory. The same reasoning applies to the developmental and regeneration biologist. I speak from experience. When I submitted our group's first paper linking regeneration and pharmacology (Pagán et al., 2013), the specific areas of expertise of the paper's reviewers (i.e., pharmacology vs. developmental biology) were immediately apparent. In a way, when responding to the reviewers I felt like a diplomat coordinating a summit between two superpowers that spoke different native languages. To have a first row seat while to scientific disciplines begin to formally collaborate is a singular honor for a scientist. Some of the immediately apparent benefits from the synergy of regeneration, development, and pharmacology research will surely include the clarification of the fundamental processes that control how an organism develops and regenerates. Moreover, this research could point the way to the discovery of small molecules that affect these processes, potentially allowing their pharmacological manipulation with obvious implications for the medical sciences. Conversely, a more complete understanding of regeneration and development could shed light important pharmacological mechanisms, as it is a well-established fact that the specific effect of many drugs is dependent on the developmental stage of the subject. I believe that this is just the beginning of a significant wave of advances in the biomedical sciences. Planarians are exceptionally positioned to help us achieve this goal, and therefore they should lead the way.

\section{Notes and Acknowledgments}

Due to space limitations it is not possible to include all the relevant work from all the research groups doing research the area. In no way do I imply that the material or references that did not make this review is unimportant or irrelevant. Please note that some aspects of the historical perspectives on planarian research were originally expressed in early form in my book "The First Brain: The Neuroscience of Planarians" published by Oxford University Press (Pagán, 2014). These were updated and expanded for this review.

My special gratitude goes to Prof. Dr. Juan Aréchaga, Editor-in-Chief of the International Journal of Developmental Biology, for kindly inviting me to write this review; it was an honor. I wish to acknowledge all past and present students of my laboratory; I have learned something of value from each and every one of them. In these lines, I want to thank one of my current research students, Ms. Mary O'Brien, who proofread this review and offered useful suggestions. I also want to express my appreciation to Dr. Jessica Sullivan-Brown, a friend and colleague at the Department of Biology, West Chester University, for her useful suggestions, proofreading, and for her invaluable insights in the area of developmental biology. I thank Dr. Harvey Sarnat (University of Calgary and Alberta's Children's Hospital) and Dr. Robert Raffa (Temple University) for their scientific work, which introduced me to the neurobiology and pharmacology of the wonderful planarians. My thanks to Dr. Antonio Carolei, for the gift of his personal reminiscences on the historical beginnings of systematic planarian pharmacology. The financial support from the Department of Biology and the College of Sciences and Mathematics, West Chester University, and the National Institutes of Health (NIH; R03DA026518), are gratefully acknowledged. The NIH did not have any role in this review, in the collection, analysis and interpretation of data, in the writing of the review or in any process related to the submission of this the paper for publication. The author declares no conflict of interests.

\section{References}

ABRIL JF, CEBRIÀ F, RODRÍGUEZ-ESTEBAN G, HORN T, FRAGUAS S, CALVO B, BARTSCHERER K, SALÓ E (2010). Smed454 dataset: unravelling the transcriptome of Schmidtea mediterranea. BMC Genomics 11: 731.

AGATAK, SOEJIMAY, KATO K, KOBAYASHIC, UMESONOY, WATANABEK (1998).
Structure of the planarian central nervous system (CNS) revealed by neuronal cell markers. Zoolog Sci 15: 433-440.

ANONYMOUS (1891). Microscopy. The Am Nat 25 : 771-772.

AKIYAMA Y, AGATAK, INOUET (2015). Spontaneous Behaviors and Wall-Curvature Lead to Apparent Wall Preference in Planarian. PLoS One 10: e0142214.

ALEXANDERBE, ACHLATISM, OSINGAR, VANDER GEESTHG, CLEUTJENS JP, SCHUTTE B, DE GOEIJ JM (2015). Cell kinetics during regeneration in the sponge Halisarca caerulea: how local is the response to tissue damage? PeerJ 3: e820.

ALONSO Á, CAMARGO JA (2015). Ammonia toxicity to the freshwater planarian Polycelis felina: contrasting effects of continuous versus discontinuous exposures. Arch Environ Contam Toxicol 68: 689-695.

ALVAREZ-PRESAS M, BAGUÑ̇̀ J, RIUTORT M (2008). Molecular phylogeny of land and freshwater planarians (Tricladida, Platyhelminthes): from freshwater to land and back. Mol Phylogenet Evol 47: 555-568.

ANDERSSON KE, CHRIST GJ (2007). Regenerative pharmacology: the future is now. Mol Interv 7: 79-86.

BAKER D, DEATS S, BOOR P, PRUITT J, PAGÁN OR (2011). Minimal structural requirements of alkyl $\gamma$-lactones capable of antagonizing the cocaine-induced motility decrease in planarians. Pharmacol Biochem Behav 100: 174-179.

BARKER JØRGENSEN C (2001). August Krogh and Claude Bernard on Basic Principles in Experimental Physiology. BioScience 51: 59-61.

BERDE C, CAIRNS B (2000). Developmental pharmacology across species: promise and problems. Anesth Analg 91: 1-5.

BEST JB, MORITA M (1991). Toxicology of planarians. Hydrobiologia 227: 375-383.

BLACKISTOND, SHOMRATT, NICOLAS CL, GRANATAC, LEVINM (2010). Asecondgeneration device for automated training and quantitative behavior analyses of molecularly-tractable model organisms. PLoS One 5: e14370.

BLACKISTON DJ, SHOMRAT T, LEVIN M (2015). The stability of memories during brain remodeling: A perspective. Commun Integr Biol 8: e1073424.

BUTTARELLI FR, PELLICANO C, PONTIERI FE (2008). Neuropharmacology and behavior in planarians: translations to mammals. Comp Biochem Physiol C Toxicol Pharmacol 147: 399-408.

CAROLEI A, MARGOTTA V, PALLADINI G (1975). Proposal of a new model with dopaminergic-cholinergic interactions for neuropharmacological investigations. Neuropsychobiology 1: 355-364.

CAROLEI A et al., (2008a) Catecholamines in Planaria. In: RAFFA RB, RAWLS SM, Editors. Planaria: A Model for Drug Action and Abuse. Austin, TX: Landes Bioscience, pp. 20-23.

CAROLEl A et al., (2008b) Opioids in Planaria. In: RAFFA RB, RAWLS SM, Editors. Planaria: A Model for Drug Action and Abuse. Austin, TX: Landes Bioscience, pp. 24-30.

CEBRIÀ F (2007). Regenerating the central nervous system: how easy for planarians! Dev Genes Evol 217: 733-748.

CEBRIÀ F, KUDOME T, NAKAZAWA M, MINETA K, IKEO K, GOJOBORI T, AGATAK (2002). The expression of neural-specific genes reveals the structural and molecular complexity of the planarian central nervous system. Mech Dev 116: 199-204.

CEBRIÀ F, KOBAYASHI C, UMESONO Y, NAKAZAWA M, MINETA K, IKEO K, GOJOBORI T, ITOH M, TAIRA M, SÁNCHEZ ALVARADO A, AGATA K (2002). FGFR-related gene nou-darake restricts brain tissues to the head region of planarians. Nature 419: 620-624

CHAN JD, ZHANG D, LIU X, ZAROWIECKI MZ, BERRIMAN M, MARCHANT JS (2016). Dataset for a Dugesia japonica de novo transcriptome assembly, utilized for defining the voltage-gated like ion channel superfamily. Data Brief9: 1044-1047.

CHRIST GJ, SAUL JM, FURTH ME, ANDERSSON KE (2013). The pharmacology of regenerative medicine. Pharmacol Rev 65: 1091-1133.

COCHET-ESCARTIN O, MICKOLAJCZYK KJ, COLLINS EM (2015). Scrunching: a novel escape gait in planarians. Phys Biol 12: 056010.

COLLINS JJ 3rd (2017) Platyhelminthes. Curr Biol 27: R252-R256.

CORNING WC, RATNER SC (Eds) (1967). The Chemistry of Learning: Invertebrate Research. Plenum Press, New York.

DORMAN D (2015). Extrapyramidal System Neurotoxicity: Animal Models. Handb ClinNeurol 131: 207-223

DURANT F, LOBO D, HAMMELMAN J, LEVIN M (2016). Physiological controls of large-scale patterning in planarian regeneration: a molecular and computational 
perspective on growth and form. Regeneration (Oxf) 3: 78-102.

EGGER B, GSCHWENTNER R, RIEGER R (2007). Free-living flatworms under the knife: past and present. Dev Genes Evol 217: 89-104.

EGGER B, STEINKE D, TARUI H, DE MULDER K, ARENDT D, BORGONIE G, FUNAYAMAN, GSCHWENTNER R, HARTENSTEIN V, HOBMAYER B, HOOGE M, HROUDAM, ISHIDAS, KOBAYASHI C, KUALES G, NISHIMURA O, PFISTER D, RIEGER R, SALVENMOSER W, SMITH J, TECHNAU U, TYLER S, AGATA K, SALZBURGER W, LADURNER P (2009). To be or not to be a flatworm: the acoel controversy. PLoS One 4: e5502.

ELLIOTT SA, SÁNCHEZ ALVARADO A (2013). The history and enduring contributions of planarians to the study of animal regeneration. Wiley Interdiscip Rev Dev Biol 2: 301-326.

EMMONS-BELL M, DURANT F, HAMMELMAN J, BESSONOV N, VOLPERT $V$, MOROKUMA J, PINET K, ADAMS DS, PIETAK A, LOBO D, LEVIN M (2015). Gap Junctional Blockade Stochastically Induces Different Species-Specific Head Anatomies in Genetically Wild-Type Girardia dorotocephala Flatworms. Int J Mol Sci 16: 27865-27896.

FRAGUAS S, BARBERÁN S, IBARRA B, STÖGER L, CEBRIÀ F (2012). Regeneration of neuronal cell types in Schmidtea mediterranea: an immunohistochemical and expression study. Int J Dev Biol 56: 143-153.

GENTILE L, CEBRIÀ F, BARTSCHERER K (2011). The planarian flatworm: an in vivo model for stem cell biology and nervous system regeneration. Dis Model Mech 4: 12-19.

GREBE E, SCHAEFFER DJ (1991). Planarians in toxicology, standardization of a rapid neurobehavioral toxicity test using phenol in a crossover study. Bull Environ Contam Toxicol 46: 866-870.

HAGSTROM D, COCHET-ESCARTIN O, COLLINS EM (2016). Planarian brain regeneration as a model system for developmental neurotoxicology. Regeneration 3: 65-77.

HAGSTROM D, COCHET-ESCARTIN O, ZHANG S, KHUU C, COLLINS EM (2015). Freshwater Planarians as an Alternative Animal Model for Neurotoxicology. Toxicol Sci 147: 270-285.

HEATH H (1907). A new turbellarian from Hawaii. Proc Acad Nat Sci Philadelphia $59: 145-148$

HOLSTEIN TW, HOBMAYER E, TECHNAU U (2003). Cnidarians: an evolutionarily conserved model system for regeneration? Dev Dyn 226: 257-267.

IMBARD A, BENOIST JF, BLOM HJ (2013). Neural tube defects, folic acid and methylation. Int J Environ Res Public Health 10: 4352-4389.

INOUE T, HOSHINO H, YAMASHITA T, SHIMOYAMA S, AGATA K (2015). Planarian shows decision-making behavior in response to multiple stimuli by integrative brain function. Zoological Lett 1: 7.

KARAMI A, TEBYANIAN H, GOODARZI V, SHIRI S (2015). Planarians: an In vivo Model for Regenerative Medicine. Int J Stem Cells 8: 128-133.

KEARNS GL, ABDEL-RAHMAN SM, ALANDER SW, BLOWEY DL, LEEDER JS, KAUFFMAN RE (2003). Developmental pharmacology-drug disposition, action, and therapy in infants and children. N Engl J Med 349: 1157-1167.

KREBS HA (1975). The August Krogh Principle: "For many problems there is an animal on which it can be most conveniently studied". J Exp Zool 194: 221-226.

KROGH A (1929). The Progress of Physiology. Science 70: 200-204.

LENTZ TL (1968). Primitive nervous systems. Yale University Press. New Haven.

LEVIN M (2012). Molecular bioelectricity in developmental biology: new tools and recent discoveries: control of cell behavior and pattern formation by transmembrane potential gradients. Bioessays 34: 205-217.

LEVIN M (2014). Molecular bioelectricity: how endogenous voltage potentials control cell behavior and instruct pattern regulation in vivo. Mol Biol Cell 25: 3835-3850.

LI MH (2016). Development of in vivo biotransformation enzyme assays for ecotoxicity screening: In vivo measurement of phases I and II enzyme activities in freshwater planarians. Ecotoxicol Environ Saf 130: 19-28.

LINDSTEDTS (2014). Krogh 1929 or 'the Krogh principle'. J Exp Biol 217: 1640-1641.

LOBO D, MALONE TJ, LEVIN M (2013). Planform: an application and database of graph-encoded planarian regenerative experiments. Bioinformatics29: 1098-1100.

MARGOTTA V, CARONTI B, MECO G, MERANTE A, RUGGIERI S, VENTURINI G, PALLADINI G (1997). Effects of cocaine treatment on the nervous system of planaria (Dugesia gonocephala s.l.). Histochemical and ultrastructural observations. Eur J Histochem 41: 223-230.
MITMAN G, FAUSTO-STERLING A (1992). Whatever happened to planaria? C.M Child and the physiology of inheritance. In (Clarke AE, Fujimura JH eds.) The Right tools for the job: at work in twentieth-century life sciences. Princeton University Press. Princeton, New Jersey.

MOORE AR (1918). Reversal of Reaction by Means of Strychnine In Planarians and Starfish. J Gen Physiol 1: 97-100.

NAYAK S, ROBERTS A, BIRES K, TALLARIDA CS, KIM E, WU M, RAWLS SM (2016). Benzodiazepine inhibits anxiogenic-like response in cocaine or ethanol withdrawn planarians. Behav Pharmacol 27: 556-558.

NEEDLEMAN HL (1967). Tolerance and dependence in the planarian after continuous exposure to morphine. Nature 215: 784-785.

NETSKY MG (1986). What is a brain, and who said so? Br Med J (Clin Res Ed) 293: 1670-1672.

NEUHOF M, LEVIN M, RECHAVI O (2016). Vertically and horizontally-transmitted memories - the fading boundaries between regeneration and inheritance in planaria. Biol Open pii: bio.020149.

NEWMARK PA, SÁNCHEZ ALVARADO A (2002). Not your father's planarian: a classic model enters the era of functional genomics. Nat Rev Genet 3: 210-219.

NEWMARK PA AND SÁNCHEZ ALVARADO A (1999). Planarian Regeneration. Encyclopedia of Life Sciences. Nature Publishing Group, London.

NISHIMURA O, HIRAO Y, TARUI H, AGATA K (2012). Comparative transcriptome analysis between planarian Dugesia japonica and other platyhelminth species. BMC Genomics 13: 289.

OKAMOTOK, TAKEUCHI K, AGATAK (2005). Neural projections in planarian brain revealed by fluorescent dye tracing. Zoolog Sci 22: 535-546.

OVIEDO NJ, MOROKUMA J, WALENTEK P, KEMA IP, GU MB, AHN JM, HWANG JS, GOJOBORI T, LEVIN M (2010). Long-range neural and gap junction proteinmediated cues control polarity during planarian regeneration. Dev Bio/339: 188-199.

PAGÁN OR (2014). The first brain: the neuroscience of planarians. Oxford University Press. New York.

PAGÁN OR (2005). Synthetic Local Anesthetics as Alleviators of Cocaine Inhibition of the Human Dopamine Transporter. PhD dissertation. Cornell University, Ithaca, NewYork.

PAGÁN OR, BAKERD, DEATS S, MONTGOMERYE, TENAGLIAM, RANDOLPH C KOTTURU D, TALLARIDA C, BACH D, WILK G, RAWLS S, RAFFA RB (2012). Planarians in pharmacology: parthenolide is a specific behavioral antagonist of cocaine in the planarian Girardia tigrina. Int J Dev Biol 56: 193-196.

PAGÁN OR, COUDRON T, KANERIAT (2009). The flatworm planaria as a toxicology and behavioral pharmacology animal model in undergraduate research experiences. J Undergrad Neurosci Educ 7:A48-A52.

PAGÁN OR, DEATSS, BAKERD, MONTGOMERYE, WILKG, TENAGLIAM, SEMON $J$ (2013). Planarians require an intact brain to behaviorally react to cocaine, but not to react to nicotine. Neuroscience 246: 265-270.

PAGÁN OR, ROWLANDS AL, AZAM M, URBAN KR, BIDJAAH, ROY DM, FEENEY RB, AFSHARI LK (2008). Reversal of cocaine-induced planarian behavior by parthenolide and related sesquiterpene lactones. Pharmacol Biochem Behav 89: $160-170$.

PALLADINIG, RUGGERIS, STOCCHIF, DEPANDIS MF, VENTURINI G, MARGOTTA V (1996). A pharmacological study of cocaine activity in planaria. Comp Biochem Physiol C Pharmacol Toxicol Endocrinol 115: 41-45.

PANG Q, GAO L, HU W, AN Y, DENG H, ZHANG Y, SUN X, ZHU G, LIU B, ZHAO B (2016). De Novo Transcriptome Analysis Provides Insights into Immune Related Genes and the RIG-I-Like Receptor Signaling Pathway in the Freshwater Planarian (Dugesia japonica). PLoS One 11: e0151597.

PASKIN TR, JELLIES J, BACHER J, BEANE WS (2014). Planarian Phototactic Assay Reveals Differential Behavioral Responses Based on Wavelength. PLoS One 9: e114708.

QINYF, FANG HM, TIAN QN, BAOZX, LUP, ZHAOJM, MAIJ, ZHUZY, SHU LL, ZHAO L, CHEN SJ, LIANG F, ZHANG YZ, ZHANG ST (2011). Transcriptome profiling and digital gene expression by deep-sequencing in normal/regenerative tissues of planarian Dugesia japonica. Genomics 97: 364-371.

PEIRIS TH, OVIEDO NJ (2013). Gap junction proteins: master regulators of the planarian stem cell response to tissue maintenance and injury. Biochim Biophys Acta 1828: 109-117.

RAFFA RB, CAVALLO F, CAPASSO A (2007). Flumazenil-sensitive dose-related 
physical dependence in planarians produced by two benzodiazepine and one non-benzodiazepine benzodiazepine-receptor agonists. Eur J Pharmacol564(13): 88-93.

RAFFA RB, DESAI P (2005). Description and quantification of cocaine withdrawal signs in Planaria. Brain Res 1032: 200-202.

RAFFA RB, HOLLAND LJ, SCHULINGKAMP RJ (2001). Quantitative assessment of dopamine D2 antagonist activity using invertebrate (Planaria) locomotion as a functional endpoint. J Pharmacol Toxicol Methods 45: 223-226.

RAFFA RB, RAWLS SM (Eds) (2008). Planaria: A Model for Drug Action and Abuse (Molecular Biology Intelligence Unit). CRC Press.

RAFFARB, STAGLIANO GW, ROSS G, POWELLJA, PHILLIPSAG, DING Z, RAWLS SM (2008). The kappa-opioid receptor antagonist nor-BNI inhibits cocaine and amphetamine, but not cannabinoid (WIN 52212-2), abstinence-induced withdrawal in planarians: an instance of 'pharmacologic congruence'. Brain Res 1193: 51-56.

RAFFA RB, VALDEZ JM (2001). Cocaine withdrawal in Planaria. Eur J Pharmacol 430: $143-145$.

RAFFA RB, VALDEZ JM, HOLLAND LJ, SCHULINGKAMP RJ (2000). Energydependent UV light-induced disruption of (-)sulpiride antagonism of dopamine. Eur J Pharmacol 406: R11-R12.

RANDOLPH H (1897). Observations and experiments on regeneration in Planarians. Archiv fürEntwicklungsmechanik der Organismen 5 : 352-372.

RAWLS SM, PATIL T, TALLARIDA CS, BARON S, KIM M, SONG K, WARD S, RAFFA $\mathrm{RB}$ (2011). Nicotine behavioral pharmacology: clues from planarians. DrugAlcohol Depend 118: 274-279.

RAWLS SM, PATIL T, YUVASHEVA E, RAFFA RB (2010). First evidence that drugs of abuse produce behavioral sensitization and cross sensitization in planarians. Behav Pharmacol 21: 301-313.

REDDIEN PW, SÁNCHEZ ALVARADO A (2004). Fundamentals of planarian regeneration. Annu Rev Cell Dev Biol 20: 725-757.

RESCH AM, PALAKODETI D, LU YC, HOROWITZ M, GRAVELEY BR (2012). Transcriptome analysis reveals strain-specific and conserved stemness genes in Schmidtea mediterranea. PLoS One 7: e34447.

RIBEIRO P, EL-SHEHABI F, PATOCKA N (2005). Classical transmitters and their receptors in flatworms. Parasitology 131 Suppl: S19-S40.

RIEGER RM (1998). 100 years of research on 'Turbellaria'. Hydrobiologia. 383: 1-27.

RILLING M (1996). The mystery of the vanished citations: James McConnell's forgotten 1960s quest for planarian learning, a biochemical engram, and celebrity. Am Psychol 51: 589-598.

RIUTORT M, ÁLVAREZ-PRESAS M, LÁZARO E, SOLÀ E, PAPS J (2012). Evolutionary history of the Tricladida and the Platyhelminthes: an up-to-date phylogenetic and systematic account. Int J Dev Biol 56: 5-17.

ROBB SM, GOTTING K, ROSS E, SÁNCHEZ ALVARADO A (2015). SmedGD 2.0: The Schmidtea mediterranea genome database. Genesis 53: 535-546.

ROBERTS-GALBRAITH RH, NEWMARK PA (2015). On the organ trail: insights into organ regeneration in the planarian. Curr Opin Genet Dev 32: 37-46.

ROHDE K (2000). Platyhelminthes (flatworms). eLS. John Wiley \& Sons Ltd. http:// www.els.net.

ROWLANDSAL, PAGÁN OR (2008). Parthenolide prevents the expression of cocaineinduced withdrawal behavior in planarians. Eur J Pharmacol 583: 170-172.

RUIZ-TRILLO I, RIUTORT M, LITTLEWOOD DT, HERNIOU EA, BAGUÑÁ J (1999). Acoel flatworms: earliest extant bilaterian Metazoans, not members of Platyhel- minthes. Science 283: 1919-23.

SACAVAGE S, PATEL H, ZIELINSKI M, ACKER J, PHILLIPSAG, RAFFARB, RAWLS SM (2008). Withdrawal-like behavior in planarians is dependent on drug exposure duration. Neurosci Lett 439: 84-88.

SALÓ E, BAGUÑÀ J (2002). Regeneration in planarians and other worms: New findings, new tools, and new perspectives. J Exp Zool 292: 528-539.

SAMARDZIC J, ALLEGAERTK, BAJCETICM (2015). Developmental pharmacology: A moving target. Int J Pharm 492: 335-337.

SARNAT HB, NETSKY MG (1985). The brain of the planarian as the ancestor of the human brain. Can J Neurol Sci 12: 296-302.

SARNAT HB, NETSKY MG (2002). When does a ganglion become a brain? Evolutionary origin of the central nervous system. Semin Pediatr Neurol 9: 240-253.

SCHAEFFER DJ (1993). Planarians as a model system for in vivo teratogenesis studies. Qual Assur 2: 265-318.

SCHWARZ D, BLOOM D, CASTRO R, PAGÁN OR, JIMÉNEZ-RIVERA CA (2011). Parthenolide Blocks Cocaine's Effect on Spontaneous Firing Activity of Dopaminergic Neurons in the Ventral Tegmental Area. Curr Neuropharmacol 9: 17-20.

SHOMRAT T, LEVIN M (2013). An automated training paradigm reveals long-term memory in planarians and its persistence through head regeneration. $J$ Exp Biol 216: 3799-3810.

STEVENS AS, PIROTTE N, PLUSQUIN M, WILLEMS M, NEYENS T, ARTOIS T, SMEETS K (2015). Toxicity profiles and solvent-toxicant interference in the planarian Schmidtea mediterranea after dimethylsulfoxide (DMSO) exposure. $J$ Appl Toxicol 35: 319-326.

STRANG J, MCDONALD R, ALQURSHIA, ROYALLP, TAYLORD, FORBESB (2016). Naloxone without the needle - systematic review of candidate routes for noninjectable naloxone for opioid overdose reversal. Drug AlcoholDepend 163: 16-23.

STRINGER CE (1917). The Means of Locomotion in Planarians. Proc Natl Acad Sci USA 3: 691-692.

STURTEVANTAH (1959). Thomas Hunt Morgan, 1866-1945. ABiographical Memoir National Academy of Sciences.

SÁNCHEZ ALVARADO A (2004a). Planarians. Curr Biol 14: R737-R738.

SÁNCHEZ ALVARADO A (2004b). Regeneration and the need for simpler model organisms. Philos Trans R Soc Lond B Biol Sci 359: 759-763.

TALBOT J, SCHÖTZ EM (2011). Quantitative characterization of planarian wild-type behavior as a platform for screening locomotion phenotypes. J Exp Biol 214: 1063-1067.

TESSMAR-RAIBLE K, ARENDT D (2003). Emerging systems: between vertebrates and arthropods, the Lophotrochozoa. Curr Opin Genet Dev 13: 331-340.

UMESONO Y, AGATA K (2009). Evolution and regeneration of the planarian central nervous system. Dev Growth Differ 51: 185-195.

UMESONO Y, TASAKI J, NISHIMURA K, INOUE T, AGATA K (2011). Regeneration in an evolutionarily primitive brain-the planarian Dugesia japonica model. Eur $J$ Neurosci 34: 863-869.

VERVOORT M (2011). Regeneration and Development in Animals. Biol Theory 6: 25.

WAYNE R, STAVES MP (1996). The August Krogh principle applies to plants. Bioscience 46: 365-369.

WILLIAMS SM, HAINES JL, MOORE JH (2004). The use of animal models in the study of complex disease: all else is never equal or why do so many human studies fail to replicate animal findings? Bioessays 26: 170-179. 


\section{Further Related Reading, published previously in the Int. J. Dev. Biol.}

The natural compound sanguinarine perturbs the regenerative capabilities of planarians

Linda Balestrini, Alessia Di Donfrancesco, Leonardo Rossi, Silvia Marracci, Maria E. Isolani, Anna M. Bianucci and Renata Batistoni

Int. J. Dev. Biol. (2017) 61: 43-52

https://doi.org/10.1387/ijdb.160169rb

Planarians in pharmacology: parthenolide is a specific behavioral antagonist of cocaine in the planarian Girardia tigrina

Oné R. Pagán, Debra Baker, Sean Deats, Erica Montgomery, Matthew Tenaglia, Clinita Randolph, Dharini Kotturu, Christopher Tallarida, Daniel Bach, Galia Wilk, Scott Rawls and Robert B. Raffa

Int. J. Dev. Biol. (2012) 56: 193-196

https://doi.org/10.1387/ijdb.113486op

Physiological and molecular characterisation of cadmium stress in Schmidtea mediterranea

Michelle Plusquin, An-Sofie Stevens, Frank Van Belleghem, Olivier Degheselle, Andromeda Van Roten, Jessica Vroonen, Ronny Blust, Ann Cuypers, Tom Artois and Karen Smeets

Int. J. Dev. Biol. (2012) 56: 183-191

https://doi.org/10.1387/ijdb.113485mp

Regeneration of neuronal cell types in Schmidtea mediterranea: an immunohistochemical and expression study

Susanna Fraguas, Sara Barberán, Begoña Ibarra, Linda Stöger and Francesc Cebrià

Int. J. Dev. Biol. (2012) 56: 143-153

https://doi.org/10.1387/ijdb.113428sf

Stem cells and neural signalling: the case of neoblast recruitment and plasticity in low dose X-ray treated planarians

Leonardo Rossi, Paola lacopetti and Alessandra Salvetti

Int. J. Dev. Biol. (2012) 56: 135-142

https://doi.org/10.1387/ijdb.123505lr

Stem cell protection mechanisms in planarians: the role of some heat shock genes Maria-Emilia Isolani, Maria Conte, Paolo Deri and Renata Batistoni

Int. J. Dev. Biol. (2012) 56: 127-133

https://doi.org/10.1387/ijdb.113432mi

Constant and continuous growth reduction as a possible cause of ageing

Etienne Geraert

Int. J. Dev. Biol. (2004) 48: 271-274

http://www.intjdevbiol.com/web/paper/031773eg

5 yr ISI Impact Factor $(2013)=2.879$
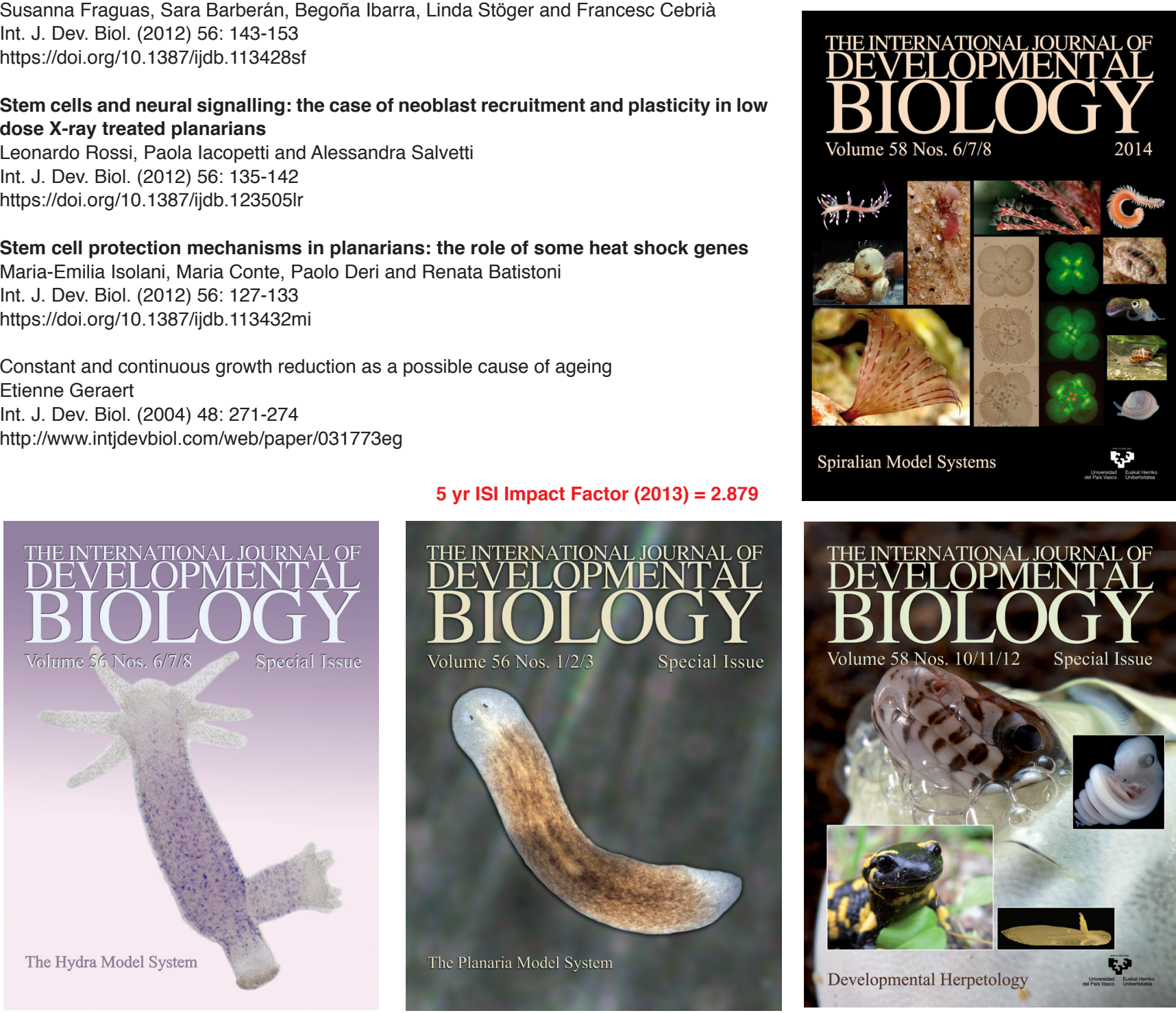